\begin{tabular}{rl|l}
$\begin{array}{c}\text { Cellular Physiology } \\
\text { and Biochemistry }\end{array}$ & \begin{tabular}{l} 
Cell Physiol Biochem 2012;30:466-476 \\
\cline { 2 - 3 } DOI: 10.1159/000339040
\end{tabular} & $\begin{array}{l}\text { O 2012 S. Karger AG, Basel } \\
\text { www.karger.com/cpb }\end{array}$ \\
\cline { 2 - 3 } & Published online: July 06, 2012 & $1015-8987 / 12 / 0302-0466 \$ 38.00 / 0$
\end{tabular}

\title{
High-grade Glioma Motility Reduced by Genetic Knockdown of KCC3
}

\author{
Kenneth B. Gagnon \\ Department of Anesthesiology, Vanderbilt University School of Medicine, Nashville, TN
}

\author{
Key Words \\ Cotransport • Gene silencing • Tracer flux • Wound assay
}

\begin{abstract}
Cell motility is dependent on a coordinated reorganization of the cytoskeleton, membrane recycling, and focal adhesion to the extracellular matrix. Each of these cellular processes involves re-distribution of cell water, which is facilitated by the transport of inorganic ions (with obligatory water movement). Scratch-wound healing assays of Wistar C6 glioblastoma cells demonstrated cell motility in advance of cell proliferation. Although bumetanide inhibition of $\mathrm{Na}-\mathrm{K}-2 \mathrm{Cl}$ cotransport activity did not affect cell motility, treatment of glioma cells with furosemide to inhibit $\mathrm{K}-\mathrm{Cl}$ cotransport activity prevented $\sim 75 \%$ of wound closure in a reversible reaction. Genetic silencing of $\mathrm{KCC} 3$ with short hairpin interfering RNA reduced protein expression by $40-60 \%, \mathrm{~K}^{+}$influx by $\sim 50 \%$, and cell motility by $\sim 50 \%$. Appearance of KCC1 mRNA and KCC3 mRNA at 25 PCR cycles versus KCC4 mRNA at 35 PCR cycles, suggests more $\mathrm{KCC} 1 / \mathrm{KCC} 3$ expression in both primary rat astrocytes and $\mathrm{C} 6$ glioma cells. Altogether, these experiments suggest that the presence/function of multiple isoforms of the $\mathrm{Na}^{+}-$ independent $\mathrm{K}-\mathrm{Cl}$ cotransporter may have a role in glioma cell motility.
\end{abstract}

Copyright (c) 2012 S. Karger AG, Basel

\section{Introduction}

Brain tumors may manifest at any age, however, peak incidence is seen in adults older than 40 years, with males being more frequently afflicted than females [1]. Glioblastoma multiformes (GBM) have small areas of necrotizing tissue surrounded by highly anaplastic 


\begin{tabular}{|c|c|c|}
\hline \multirow{3}{*}{$\begin{array}{l}\text { Cellular Physiolosy } \\
\text { and Biochemistry }\end{array}$} & \multirow{2}{*}{$\begin{array}{l}\text { Cell Physiol Biochem 2012;30:466-476 } \\
\text { DOI: 10.1159/000339040 }\end{array}$} & \\
\hline & & $\begin{array}{l}\text { O } 2012 \text { S. Karger AG, Basel } \\
\text { www.karger.com/cpb }\end{array}$ \\
\hline & Gagnon: Role of KCC3 in Glio & \\
\hline
\end{tabular}

cells. The aberrant proliferation, diminished apoptosis, robust angiogenesis, and invasiveness of high-grade gliomas makes complete surgical removal nearly impossible [2,3]. The average survival time for patients diagnosed with GBMs is less than 12 months. Overall, few patients diagnosed with a brain tumor survive beyond 3 years [4]. GBMs can form in either the grey matter or white matter of the brain, but most arise from the deep white matter and quickly infiltrate the grey matter of the brain, often becoming very large before producing symptoms [5]. Gliomas of this type usually occur in more than one lobe of a hemisphere or infiltrate across the corpus callosum, producing a butterfly or bilateral tumor [5].

Glioblastoma cell invasion involves protease degradation of extracellular matrix, formation and degradation of focal adhesions, and a coordinated reorganization of the cytoskeleton to allow tumor cells to migrate through healthy brain tissue [6-9]. Localized cell volume changes associated with these processes require movement of cell water coupled to transport of inorganic ions. Several studies suggest that chloride conductance is essential for migration in glioma cells, human monocytes, transformed renal epithelial cells, carcinoma cells, and microglial cells [10-14]. In 2006, Stock and co-workers demonstrated an asymmetric distribution of several ion and water transport proteins (e.g. $\mathrm{Na}^{+} / \mathrm{H}^{+}$exchanger, $\mathrm{Na}-\mathrm{K}-2 \mathrm{Cl}$ and $\mathrm{K}-\mathrm{Cl}$ cotransporters, $\mathrm{K}^{+}$channels, aquaporins) had a significant role in cell migration [1517]. The electroneutral cation-chloride cotransporters are excellent candidates as transport proteins involved in cell migration. Indeed, from their original functional characterization in the early 1980s, it is well recognized that the activities of $\mathrm{K}-\mathrm{Cl}$ and $\mathrm{Na}-\mathrm{K}-2 \mathrm{Cl}$ cotransporters are closely related to and affected by cell volume. Small increases in cell volume (swelling) are known to significantly activate KCC [18] whereas small decreases in cell volume (shrinkage) tend to inhibit $\mathrm{KCC}$ and activate $\mathrm{Na}-\mathrm{K}-2 \mathrm{Cl}$ cotransport [19]. The Sontheimer laboratory recently demonstrated a role for NKCC1 in the invasive migration of human glioma cells [20], and semi-quantitative RT-PCR demonstrated an up-regulation of KCC1, KCC3, and KCC4 mRNA transcripts in malignant human cervical epithelial cells [21, 22]. Another study using whole cell lysates isolated from two glioblastoma patients demonstrated greater quantities of KCC1 and KCC3a protein than that of primary cultured cortical astrocytes [23].

In this study, the role of $\mathrm{K}-\mathrm{Cl}$ cotransport in glioma cell motility was investigated using the Wistar C6 glioma tumor model. Greater cell motility was observed in untreated cells versus furosemide treated cells and genetic silencing of KCC3 reduced protein expression, $\mathrm{K}^{+}$influx, and cell motility by $\sim 50 \%$. Semi-quantitative PCR of total RNA indicates that both primary astroctyes and C6 glioma cells have differing mRNA expression levels of the $\mathrm{K}-\mathrm{Cl}$ cotransporters, and combined with the other data suggest that presence/function of multiple $\mathrm{Na}^{+}$-independent $\mathrm{K}-\mathrm{Cl}$ cotransporters have a role in glioma cell motility.

\section{Materials and Methods}

\section{Primary Rat Astrocyte Isolation}

Primary astrocytes were prepared from the cerebral cortices of 3 day-old Sprague-Dawley rats (Harlan, IN, USA) as previously described [24]. Briefly, cerebral cortical tissue was dissected, minced, and suspended in 10 volumes $0.05 \%(\mathrm{w} / \mathrm{v})$ trypsin/EDTA and incubated for $10 \mathrm{~min}$ at $37^{\circ} \mathrm{C}$. The cell suspension was passed through a 14-gauge needle five times, and then filtered through $85 \mu \mathrm{m}$ nylon mesh. The filtrate was sedimented by centrifugation at $200 \mathrm{~g}$ for $5 \mathrm{~min}$ and re-suspended Dulbecco's Minimum Essential Medium (DMEM) containing $10 \%$ fetal bovine serum, penicillin $100 \mathrm{U} / \mathrm{ml}$, and streptomycin $100 \mu \mathrm{g} / \mathrm{ml}$. Finally, cells were transferred to T-75 cell culture flasks $\left(75 \mathrm{~cm}^{2}\right.$ growth area), incubated at $37^{\circ} \mathrm{C}$ in a $95 \% \mathrm{O}_{2} / 5 \% \mathrm{CO}_{2}$ gas atmosphere, with fresh medium changes the next day and then every 2 days afterwards.

After 7-9 days, T-75 flasks of confluent cells were shaken at $200 \mathrm{rpm}$ on an orbital shaker for $4 \mathrm{~h}$ at room temperature to remove any residual microglial cells, and then rinsed three times with phosphatebuffered saline (PBS). Trypsinized cells were then re-suspended in DMEM containing 10\% fetal bovine serum, penicillin $100 \mathrm{U} / \mathrm{ml}$, and streptomycin $100 \mu \mathrm{g} / \mathrm{ml}$, and sub-cultured in $20 \mathrm{~cm}$ diameter cell culture plates (314 $\mathrm{cm}^{2}$ growth area) for RNA extraction. 


\begin{tabular}{|c|c|c|}
\hline Cellular Phvi & Cell Physiol Biochem 2012;30:466-476 & \\
\hline nd Biochemistry & $\begin{array}{l}\text { DOI: 10.1159/000339040 } \\
\text { Published online: July 06, } 2012\end{array}$ & $\begin{array}{l}\text { (c) } 2012 \text { S. Karger AG, Basel } \\
\text { www.karger.com/cpb }\end{array}$ \\
\hline
\end{tabular}

Table 1. PCR primer sequences for rat potassium-chloride cotransporters. Size of the PCR products in base pairs indicated in the last column.

\begin{tabular}{lllr}
\hline Gene & Sense $\left(5^{\prime}\right.$ to $3^{\prime}$ ) & Antisense (5' to 3') & Size \\
\hline KCC1 & CGGACAGGGTAACCACAGAG & AGCCGCAGGAAGAGGATGACCC & 309 \\
KCC2 & ACGGACTGCGAGGACGGCGATGG & TGCAGGCACGGCAGGTACACACC & 311 \\
KCC3 & AGCTCAAGGCAGGAAAGGGAC & ATCTTCACTCTGACGCCAGCC & 263 \\
KCC4 & GGAGATGGAAACCCCAGGGA & TCCGATGAAGGTGCCCATGC & 246 \\
\hline
\end{tabular}

Table 2. RNA sequence of shRNA molecules used to knock down $\mathrm{K}-\mathrm{Cl}$ cotransporter - isoform 3. Human Mir30, a regulatory micro-RNA, is depicted as a short-hairpin structure. Three different specific sequences (\#) targeting rat KCC3 were inserted in place of "NNN..." in the human Mir30 structure.

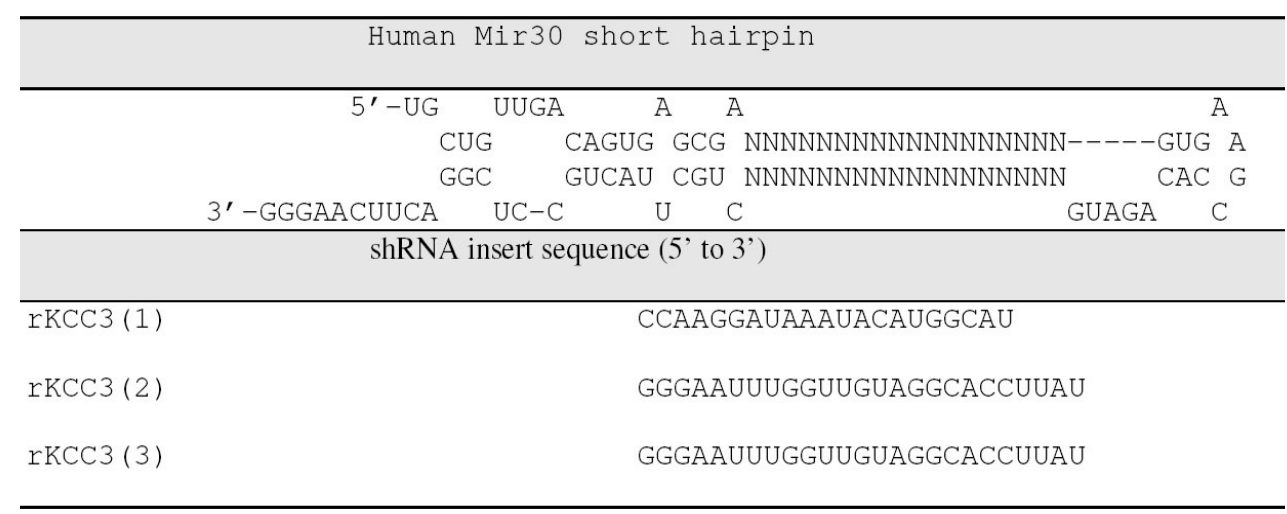

\section{Immortalized cell culture}

Wistar C6 glioma cells obtained from American Type Culture Collection (Manassas, VA) were incubated in Dulbecco's Modified Eagle Medium (containing L-glutamine, 15\% horse serum, 2\% fetal bovine serum, and penicillin $100 \mathrm{U} / \mathrm{ml}$, and streptomycin $100 \mu \mathrm{g} / \mathrm{ml}$ ) at $37^{\circ} \mathrm{C}$ in a $95 \% \mathrm{O}_{2} / 5 \% \mathrm{CO}_{2}$ gas atmosphere. Monolayers of cells were grown to confluence in $20 \mathrm{~cm}$ diameter cell culture plates $\left(314 \mathrm{~cm}^{2}\right.$ growth area) for RNA extraction, $3.5 \mathrm{~cm}$ diameter cell culture dishes with a $0.16 \mathrm{~mm}$ thick glass coverslip insert $\left(1.5 \mathrm{~cm}^{2}\right.$ growth area) for scratch-wound assay experiments, and 12 -well culture plates $\left(3.8 \mathrm{~cm}^{2}\right.$ growth area) for ${ }^{86} \mathrm{Rb}$ tracer flux experiments.

Polymerase chain reaction

Confluent $20 \mathrm{~cm}$ diameter cell culture plates $\left(314 \mathrm{~cm}^{2}\right.$ growth area) of C6 glioma cells were first washed with ice-cold HEPES-buffered PBS, and then RNA was isolated using the RNeasy kit from Qiagen (Valencia, CA). Total RNA (250 ng) was then reverse transcribed with random hexamers and Superscript ${ }^{\circledR}$ II (Invitrogen, Grand Island, NY). Semi-quantitative PCR of primary rat astrocytes and C6 glioma cell RNA (with primers listed in Table 1) was performed by removing amplification reactions every 5 cycles (denaturation, $1 \mathrm{~min}$ at $94^{\circ} \mathrm{C}$; annealing, $1 \mathrm{~min}$ at $55^{\circ} \mathrm{C}$; and extension, $1 \mathrm{~min}$ at $68^{\circ} \mathrm{C}$ ) after the $20^{\text {th }}$ cycle. The contents of each independent reaction tube were analyzed by $2 \%$ agarose gel electrophoresis, and visualized with $0.005 \%$ ethidium bromide.

\section{Short-hairpin RNA knockdown}

Three regions of KCC3 suitable for short hairpin RNA (shRNA) genetic silencing were identified using BLOCK-iT ${ }^{\mathrm{TM}}$ RNAi Designer software (Invitrogen), and synthesized as short hairpins that adopted the human micro RNA Mir30 structure (see Table 2) [25]. The human Mir30 sequences with overhangs compatible with AgeI and EcoRI restriction sites were inserted into a shRNA compatible mammalian expression vector [26]. Using Fugene 6, the pLKO2 expression vectors containing the shRNA constructs were transfected into $10 \mathrm{~cm}$ cell culture dishes $\left(78 \mathrm{~cm}^{2}\right.$ growth area) of non-confluent cultures of C6 glioma cells, and allowed to reach confluency $(\sim 48 \mathrm{~h})$. Increasing concentrations of puromycin in the cell growth media was used to select for daughter cells which had stably incorporated the shRNA. 


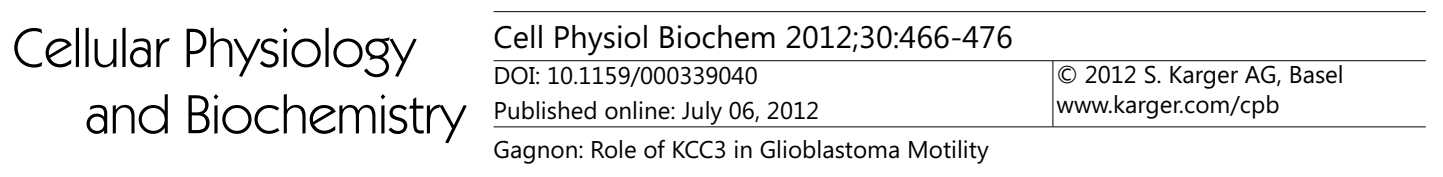

Fig. 1. NKCC1 activity is not involved in glioma cell motility. A) DIC microscopy of non-transfected glioma cells (nt) cultured on glass coverslips and incubated with DMSO, $5 \mu \mathrm{M}$, and $20 \mu \mathrm{M}$ bumetanide. Dashed lines demarcate the edges of the wound area at $0,2,4$, and $6 \mathrm{~h}$ post-wounding. All panels are 5 $\mathrm{x}$ magnification. Scale bar $=300 \mu \mathrm{m}$. B) Bar graph of TScratch measurements of wound healing assay shown in (A). DMSO was used as a drug vehicle and non-treatment control. Difference from: $\mathrm{T}=0\left(^{*}\right)$; from previous time point (\#). Statistical significance measured by one-way ANOVA $(\mathrm{p}<0.01)$. Data points represent mean +/- SE of multiple measurements $(n=6)$.

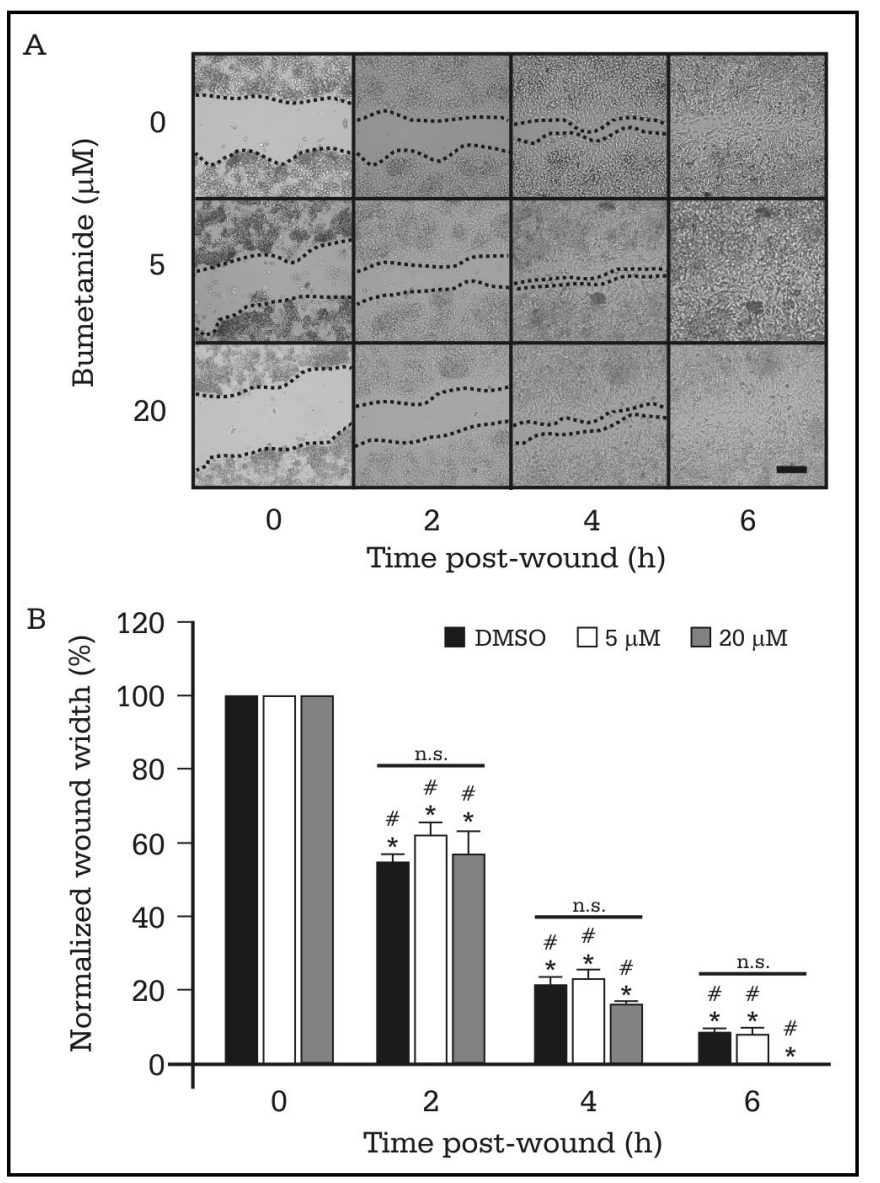

Western blot Analysis

Cell lysates from two confluent $20 \mathrm{~cm}$ diameter cell culture plates $\left(314 \mathrm{~cm}^{2}\right.$ growth area) for nontransfected and shRNA transfected C6 cells, respectively, were combined and microsomes of plasma membrane were prepared using 3 successive centrifugations $(4000,9000$, and $27000 \mathrm{rpm}$ ) in a $0.32 \mathrm{M}$ sucrose solution containing $5 \mathrm{mM}$ TRIS (pH 7.5), $2 \mathrm{mM}$ EDTA, and $2.5 \mathrm{mM} \beta$-mercaptoethanol. Equivalent amounts of microsomal protein (measured via BioRad Bradford assay) were resolved by $9 \%$ SDS-PAGE and electroblotted to PVDF membranes using a semi-dry transfer apparatus (Owl Scientific) at $110 \mathrm{~mA}$ for 90 min. Membranes were then blocked for $2 \mathrm{~h}$ at room temperature with $5 \%$ nonfat dry milk in TBS-T $(150 \mathrm{mM} \mathrm{NaCl}, 10 \mathrm{mM}$ Tris $\mathrm{HCl}, 0.5 \%$ (v/v) Tween 20), and incubated with a rabbit polyclonal anti-KCC3 antibody (1:1000, generous gift from Dr. Eric Delpire, Vanderbilt University School of Medicine, Nashville, $\mathrm{TN}$ ) in $5 \%$ nonfat dry milk in TBS-T overnight at $4^{\circ} \mathrm{C}$. The following day, after extensive washes in TBS$\mathrm{T}$, the membrane was incubated with anti-rabbit HRP-conjugated (1:5000) and anti-actin HRP-conjugated (1:30000) antibodies in 5\% nonfat dry milk in TBST for $1 \mathrm{~h}$. After another series of washes in TBS-T, the membrane was treated with enhanced chemiluminescence reagent (Amersham Biosciences, Piscataway, NJ), and exposed to Kodak BioMax X-Ray film (PerkinElmer, Boston, MA) to visualize protein bands.

${ }^{86} \mathrm{Rb}$ tracer flux assays

Non-transfected and shRNA knock-down glioma cell cultures grown in 12 -well plates $\left(3.8 \mathrm{~cm}^{2}\right.$ growth area) were washed twice with room temperature isotonic $\mathrm{Na}^{+}$-free solution (150 mM NMDG-Cl, $5 \mathrm{mM} \mathrm{KCl}$, $2 \mathrm{mM} \mathrm{CaCl}, 0.8 \mathrm{mM} \mathrm{MgSO}_{4}, 5 \mathrm{mM}$ glucose, $5 \mathrm{mM}$ HEPES, $\mathrm{pH} 7.4$ ) then pre-incubated for 15 min with the isotonic $\mathrm{Na}^{+}$-free solution containing $1 \mathrm{mM}$ ouabain. Following pre-incubation, cells were incubated with an isotonic $\mathrm{Na}^{+}$-free solution containing $1 \mathrm{mM}$ ouabain and $1 \mu \mathrm{Ci} / \mathrm{ml}{ }^{86} \mathrm{Rb}$. Tracer influx was terminated after 30 min by 4 washes with ice-cold isotonic $\mathrm{Na}^{+}$-free solution. Cells were lysed with $500 \mu \mathrm{l} \mathrm{N} \mathrm{NaOH}$ for $1 \mathrm{~h}$, and neutralized with $250 \mu \mathrm{l}$ glacial acetic acid. A $150 \mu \mathrm{l}$ sample of the cell lysate was mixed with $5 \mathrm{ml}$ scintillation cocktail for measurement. Protein concentration was determined from the remaining lysate by Bradford assay, and $\mathrm{K}^{+}$influx expressed in $\mathrm{nmol} / \mathrm{mg}$ protein/min. Each experimental condition was measured in triplicate. 


\begin{tabular}{|c|c|c|}
\hline rall & Cell Physiol Biochem 2012;30:466-476 & \\
\hline and Biochemistry & $\begin{array}{l}\text { DOI: 10.1159/000339040 } \\
\text { Published online: July 06, } 2012\end{array}$ & $\begin{array}{l}\text { (c) } 2012 \text { S. Karger AG, Basel } \\
\text { www.karger.com/cpb }\end{array}$ \\
\hline
\end{tabular}

Fig. 2. KCC activity is involved in glioma cell motility. A) DIC microscopy of nontransfected glioma cells (nt) cultured on glass coverslips were incubated with DMSO, $50 \mu \mathrm{M}, 200 \mu \mathrm{M}$, and $1000 \mu \mathrm{M}$ furosemide. Dashed lines demarcate the edges of the wound area at $0,2,4$, and $6 \mathrm{~h}$ post-wounding. Asterisk denotes $6 \mathrm{~h}$ after replacement of furosemide-containing media with fresh cell culture media (i.e. $12 \mathrm{~h}$ after wounding). All panels are $5 \mathrm{x}$ magnification. Scale bar $=300 \mu \mathrm{m}$. B) Bar graph of TScratch measurements of wound healing assay shown in (A). DMSO used as a drug vehicle and non-treatment control. Difference from $\mathrm{T}=0\left({ }^{*}\right)$; from previous time point (\#); and from DMSO within time point (+). Statistical significance measured by one-way ANOVA ( $p<0.01)$. Data points represent mean $+/$ - SE of multiple measurements $(n=6)$.

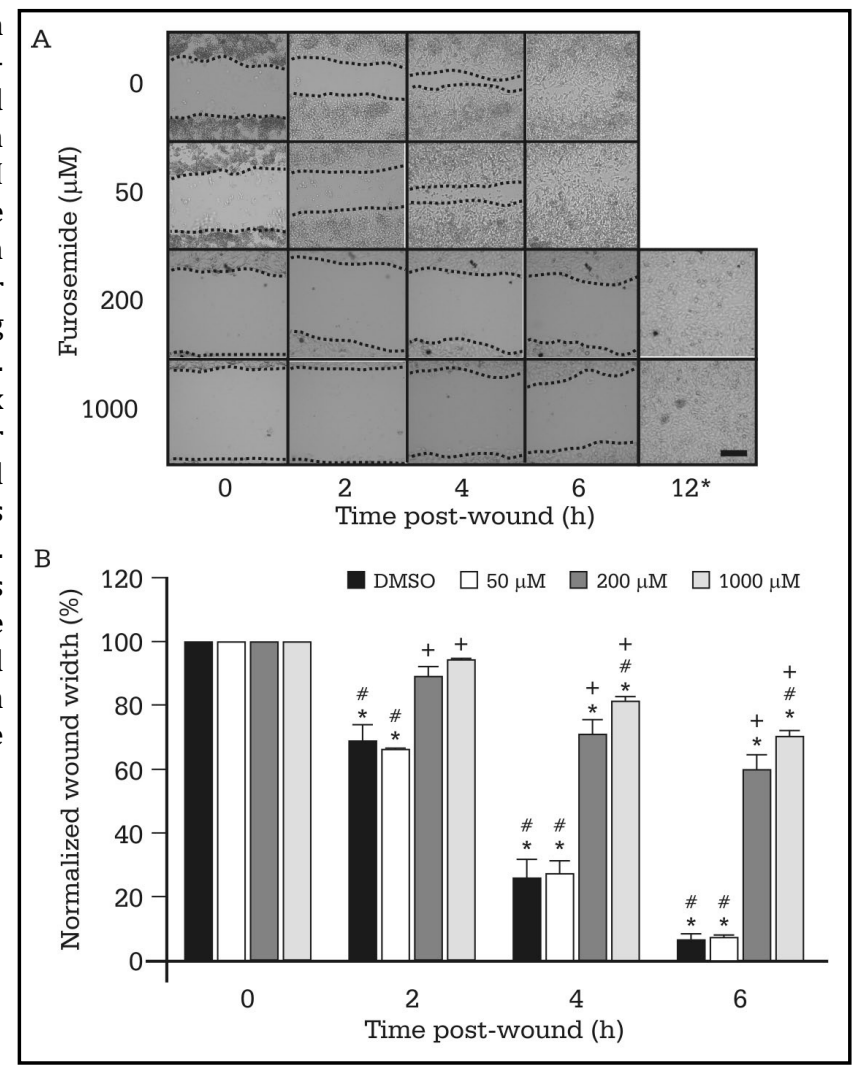

Scratch wound assay

Wistar C6 glioma cells were grown on glass coverslips $\left(1.5 \mathrm{~cm}^{2}\right.$ growth area) inset into $3.5 \mathrm{~cm}$ diameter plastic cell culture dishes. Each confluent dish was then "scratched" with a $20 \mu$ pipette tip to create a gap in the monolayer, washed once with PBS, then maintained at $37^{\circ} \mathrm{C}$ in Dulbecco's Modified Eagle Medium. Using differential interference contrast (DIC) microscopy, images were captured at five time points $(0,2,4,6$, and $12 \mathrm{~h}$ ) to measure 'wound closure' as an estimate of cell motility. DIC microscopy was also used to image nontransfected and shRNA treated C6 glioma cells at initial time of 'wounding' and $8 \mathrm{~h}$ later. Measurement of wound area was accomplished using TScratch, an open source software tool which automatically analyzes wound healing assays [27].

Statistical analysis

Statistical differences between groups were tested using one-way ANOVA with GraphPad Instat 3 software. $P$ values $<0.01$ were considered to be significant.

\section{Results}

Effect of loop diuretics on glioma cell motility

The Wistar C6 glioblastoma cell line has been used extensively as an in vitro cell model for brain tumor research [28-33]. Although bumetanide and furosemide are each capable of inhibiting both NKCC and KCC activity, their functional efficacies can be used to differentiate between the $\mathrm{Na}^{+}$-dependent and $\mathrm{Na}^{+}$-independent $\mathrm{K}-\mathrm{Cl}$ cotransporters $[34,35]$. Measurement of C6 cell motility in a wound healing assay every $2 \mathrm{~h}$ found no significant difference (oneway ANOVA, $\mathrm{p}>0.01$ ) between drug vehicle (DMSO), $5 \mu \mathrm{M}$, and $20 \mu \mathrm{M}$ bumetanide at each time point (Fig. 1A/B). Although treatment of C6 cells with $50 \mu \mathrm{M}$ furosemide allowed wound closure similar to that of DMSO (drug vehicle), as shown in Figure 2A/B, $200 \mu \mathrm{M}$ and 1000 $\mu \mathrm{M}$ concentrations of furosemide significantly inhibited wound closure in the first $2 \mathrm{~h}$ (oneway ANOVA, $\mathrm{p}<0.01$ ). Six $\mathrm{h}$ after replacement of furosemide-containing media with normal DMEM cell culture media, the wound area was completely closed indicating that inhibition of cell motility at $200 \mu \mathrm{M}$ and $1000 \mu \mathrm{M}$ furosemide was totally reversible (Fig. 2A). 


\section{Cellular Physiology $\quad$ Cell Physiol Biochem 2012;30:466-476 \\ \begin{tabular}{ll|l} 
and Biochemistry & $\begin{array}{l}\text { DOI: 10.1159/000339040 } \\
\text { Published online: July 06, } 2012\end{array}$ & $\begin{array}{l}\text { × } 2012 \text { S. Karger AG, Basel } \\
\text { www.karger.com/cpb }\end{array}$ \\
\cline { 2 - 3 } Gagnon: Role of KCC3 in Glioblastoma Motility &
\end{tabular}}

Fig. 3. KCC3 protein expression is reduced by shRNA gene silencing. A) Western blot of non-transfected glioma cells (nt) and glioma cells stably expressing one of three KCC3 shRNAs (\#) with rb anti-KCC3 (upper panel) and anti-actin HRP (lower panel) antibodies. Blot representative of three independent experiments. B) Ratio of KCC3/ Actin densitometry of western blot panels in 5A. C) ${ }^{86} \mathrm{Rb}$ tracer $\mathrm{K}^{+}$influx of non-transfected glioma cells (nt) and the three stable KCC3 shRNA-expressing glioma cells (\#) in a $\mathrm{Na}^{+}$-free solution containing $1 \mathrm{mM}$ ouabain and $1 \mu \mathrm{Ci} /$ $\mathrm{ml}^{86} \mathrm{Rb}(\mathrm{n}=3)$.

\begin{tabular}{lccc}
\hline & \multicolumn{3}{c}{ shRNA sequence (\#) } \\
& 1 & 2 & 3 \\
\hline KCC1 & 71 & 76 & 76 \\
KCC2 & 67 & 72 & 76 \\
KCC3 & 100 & 100 & 100 \\
KCC4 & 71 & 64 & 76
\end{tabular}

Table 3. Selectivity of shRNA sequences for rat $\mathrm{K}-\mathrm{Cl}$ cotransporter isoforms. Alignment (\%) of KCC3 shRNA sequences to demonstrate nonselectivity.

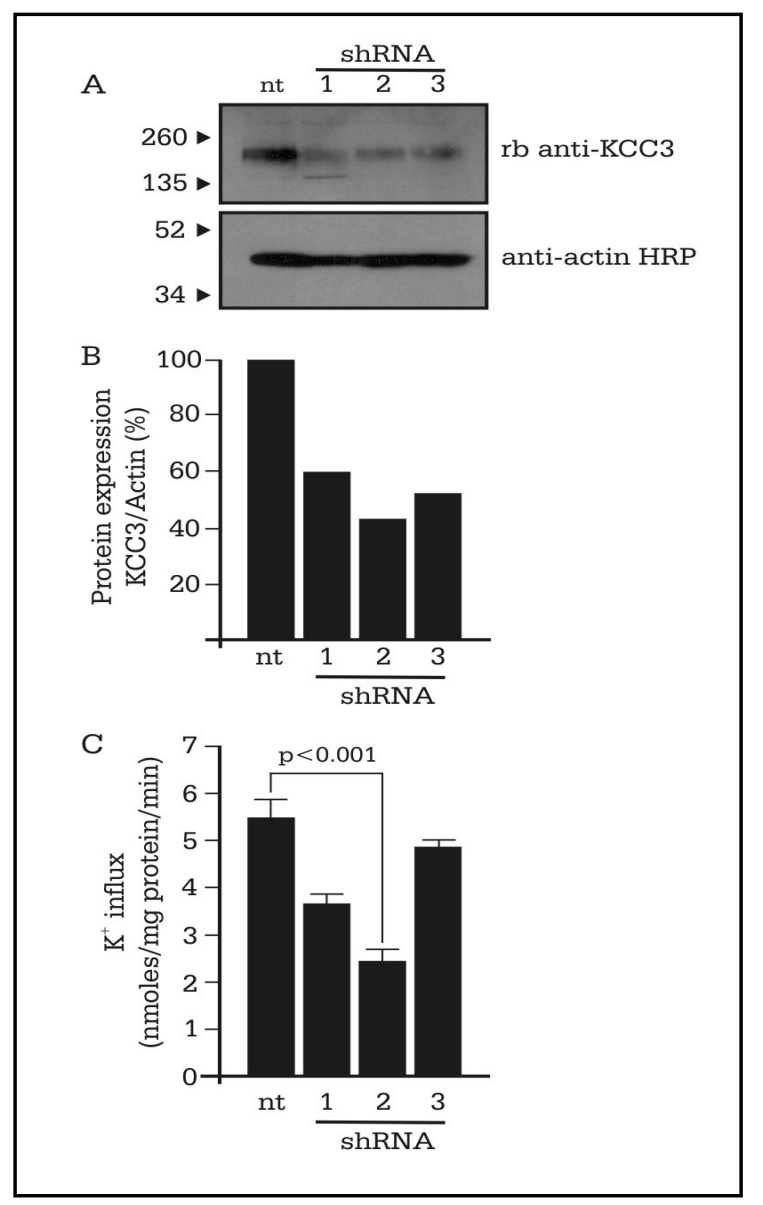

Short-hairpin RNA silencing reduces protein expression of KCC3

Puromycin selection was used to create three novel glioma cell lines stably expressing different KCC3 short hairpin RNAs inserted into a mammalian expression vector with a U6 promoter (see Table 2). Short hairpin RNA (shRNA) is a variant of RNA interference where a sequence of RNA forms a tight hairpin turn and silences gene expression [36]. Plasma membrane microsomes prepared from cell lysates of confluent $20 \mathrm{~cm}$ cell culture dishes (314 $\mathrm{cm}^{2}$ growth area) of non-transfected and the three KCC3 knock-down cell lines were separated by SDS-PAGE. Western blot of PVDF membranes showed reduced expression of KCC3 in all three knock-down cell lines compared to non-transfected tumor cells (Fig. 3A). When normalized with the ECL signal from an anti-actin HRP-conjugated antibody, the second shRNA expressing cell line had the greatest reduction in KCC3 protein expression (Fig. 3B). It is important to note that even with shRNA oligonucleotides that exactly match rat KCC3 (see Table 3), the maximum level of KCC3 protein reduction was only 50\% (Fig. 3B).

\section{KCC3 knockdown reduces $K^{+}$influx by $\sim 50 \%$}

To assess $\mathrm{K}-\mathrm{Cl}$ cotransport function, ${ }^{86} \mathrm{~Kb}^{+}$tracer flux experiments were performed on confluent non-transfected and the three KCC3 knock-down glioma cell lines cultured in an isotonic $\mathrm{Na}^{+}$-free solution containing $1 \mathrm{mM}$ ouabain (see Fig. $3 \mathrm{C}$ ). In this way, all $\mathrm{Na}^{+}-$ dependent ion movement through the $\mathrm{Na}-\mathrm{K}-2 \mathrm{Cl}$ cotransporter and the $\mathrm{Na}^{+} / \mathrm{K}^{+}$ATPase were eliminated. Consistent with the protein densitometry (see Fig. 3B), the second shRNA tumor cell line had a $\sim 50 \%$ reduction in $\mathrm{K}^{+}$influx compared to non-transfected tumor cells $(2.1$ nmoles/mg protein/min vs $5.5 \mathrm{nmoles} / \mathrm{mg}$ protein/min, One-Way ANOVA, $\mathrm{p}<0.001$ ). 
Fig. 4. Cell motility reduced by shRNA gene silencing of KCC3. A) DIC microscopy of non-transfected glioma cells (nt) cultured on glass coverslips at $0 \mathrm{~h}$ and $8 \mathrm{~h}$. B) DIC microscopy of glioma cells stably expressing KCC3 shRNA (2) at 0 $\mathrm{h}$ and $8 \mathrm{~h}$. Right panels are $40 \mathrm{x}$ magnification of dashed box regions in left panels. Scale bars for both left and right panels $=100 \mu \mathrm{m}$. C) Bar graph of TScratch measurements from wound healing assays in (A) and (B) $(n=3)$. Difference from: $T=0$ (*); within time point (\#). Statistical significance measured by one-way ANOVA $(\mathrm{p}<0.01)$.

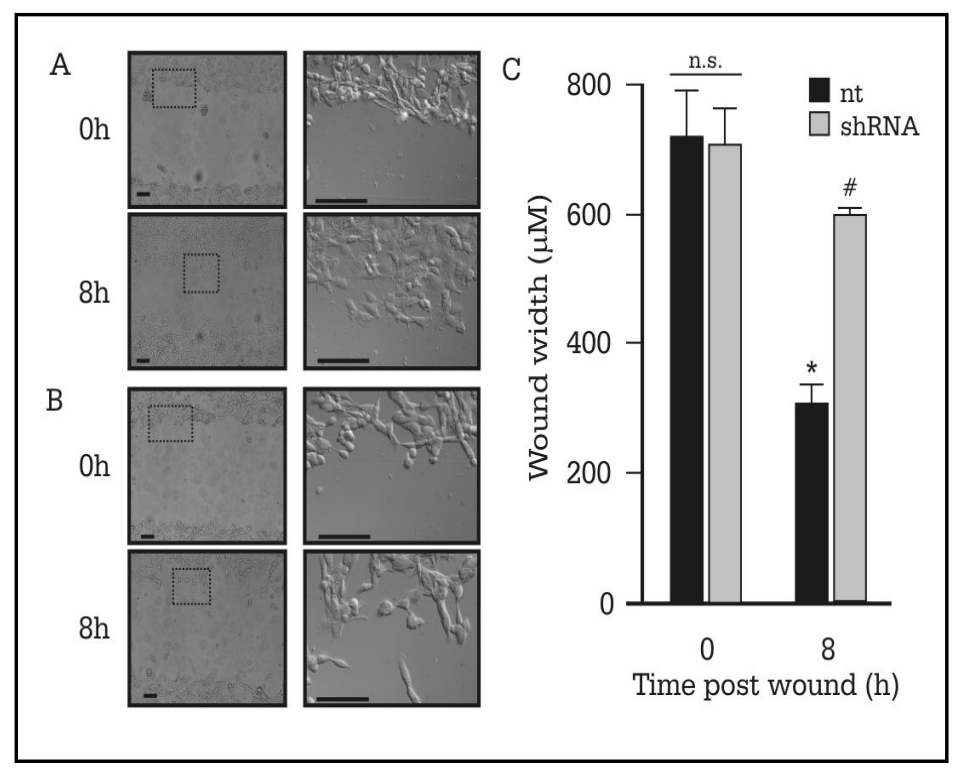

Fig. 5. Multiple KCC isoforms are expressed in primary rat astrocytes and C6 glioma cells. PCR amplification of reverse-transcribed primary astrocyte and tumor cell mRNA at 20, 25, 30, and 35 cycles with primers for KCC1; KCC3; and KCC4. Solid arrows denote where signal is first detected for each isoform in primary rat astrocytes (left panels) and C6 glioma cells (right panels). PCR experiment was repeated once using cDNA reverse transcribed from separate RNA isolations.

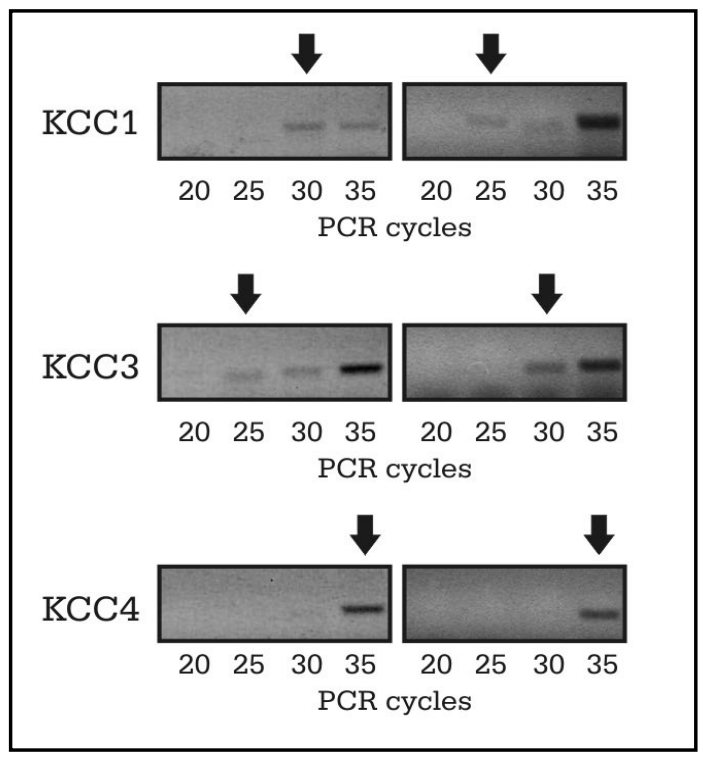

KCC3-deficient C6 glioma cell motility reduced by $50 \%$

The inhibition of cell motility with 200 and $1000 \mu \mathrm{M}$ furosemide (see Fig. 2A/B) suggest a role of $\mathrm{K}-\mathrm{Cl}$ cotransport in cell migration. However, as high-doses of furosemide could have non-specific effects separate from inhibition of $\mathrm{K}-\mathrm{Cl}$ cotransport activity, the scratch wound assay was repeated with the non-transfected and the shRNA knock-down glioma cell line \#2. Comparison of DIC microscopy images $8 \mathrm{~h}$ after wounding shows flattened migrating nontransfected cells (Fig. 4A) and rounded non-motile knock-down cells (Fig. 4B). Averaging six independent measurements of wound areas for both cell lines at 0 and $8 \mathrm{~h}$ confirms that the shRNA knock-down cell lines motility was reduced $\sim 50 \%$ (Fig. 4C).

\section{Cotransporter expression in C6 glioma cells}

The observation that shRNA knockdown of KCC3 only reduced cell motility by half, prompted a determination whether the expression of another KCC isoform might have a role in cell motility. Semi-quantitative PCR experiment with new primer pairs specific to each isoform (see Table 1) were performed by removing PCR reactions every 5 cycles beginning at 20 cycles. Ethidium bromide labeled PCR products from both primary astrocytes (left panels) and C6 tumor cells (right panels) confirmed enhanced amplification of KCC3 at 


\section{Cellular Physiology Cell Physiol Biochem 2012;30:466-476 \\ \begin{tabular}{ll|l} 
and Biochemistry & $\begin{array}{l}\text { DOI: 10.1159/000339040 } \\
\text { Published online: July 06, } 2012\end{array}$ & $\begin{array}{l}\text { ○ 2012 S. Karger AG, Basel } \\
\text { www.karger.com/cpb }\end{array}$ \\
\cline { 2 - 3 } Gagnon: Role of KCC3 in Glioblastoma Motility &
\end{tabular}}

25-30 cycles (denoted by block arrows in Fig. 5). Expression of KCC1 is similar to that of $\mathrm{KCC} 3$, as amplification is also observed at 25-30 cycles in both primary and C6 cells, whereas expression of KCC4 is much lower, as the signal only appears at 35 cycles. Note that KCC2 was also tested and demonstrated to be absent in both cell types (data not shown). These data, showing similar mRNA expression levels of KCC1 and lower mRNA expression of KCC4, are consistent with the hypothesis of other KCC isoforms contributing to the function and motility of the KCC3 shRNA knock-down glioma cell lines.

\section{Discussion}

Brain tumors are second only to stroke as the leading cause of death from neurological disease. Primary brain tumors develop from cancerous cells located within the brain, whereas, metastatic brain tumors are a result of other cancers (e.g. lung, colon, kidney, thyroid, and breast) spreading to the brain [37]. Glioblastoma multiforme (GBM), the most aggressive form of primary brain tumor, has a median survival time of 12-14 months [38]. Malignant primary brain tumors, however, invade neighboring brain tissue through cell proliferation, migration, and invasion [2,3]. Directed locomotion of migrating cells involves a coordinated reorganization of the cytoskeleton, membrane recycling, and focal adhesion to the extracellular matrix - activities which all significantly perturb cell volume homeostasis.

Loss of KCC efflux activity could result in an increase in the intracellular chloride concentration, which has been shown to affect the activity of cell cycle regulators and the expression of integrins and matrix metalloproteinases [22, 39, 40]. Furthermore, growth factors implicated in cancer cell migration and invasion have also been co-localized with KCC activity and expression [41-44]. In the current study, the C6 glioma cell model was used to test if KCC activity might also have a role in glioblastoma cell motility.

Bumetanide concentrations sufficient to inhibit NKCC1 activity did not affect cell motility in the scratch wound assay. This is consistent with a wound healing assay of human grade IV glioma cell lines [20]. However, bumetanide did inhibit glioma cell invasion through $3 \mu \mathrm{m}$ pore transwell barriers by $\sim 50 \%$ [20]. The contradictory effects of bumetanide between the scratch wound assay and a transwell barrier assay might be that the former measures cell motility on a planar surface, and the latter measures cell invasiveness in a restricted environment [20]. Another possibility is that at the leading edge of the cell, other bumetanide-insensitive salt and water transport mechanisms are available to participate in cell movement, thus application of bumetanide does not necessarily hinder glioma cell motility. Another scratch wound assay was performed with concentrations of furosemide compatible with the IC50 of the diuretic on K-Cl cotransport [16]. Inhibition of cell motility with furosemide is consistent with another study that demonstrated KCC activity as an important modulator of cervical cancer growth and invasiveness [21, 22]. The application of furosemide concentrations $>200 \mu \mathrm{M}$ inhibited all $\mathrm{K}-\mathrm{Cl}$ cotransporter activity [35]. As a result, the intracellular $\mathrm{Cl}^{-}$concentration would significantly increase and likely modulate processes involved in cell motility. The 'reversibility' of the furosemide effect is possibly a result of 'diuretic-cotransporter complex' internalization and, in fact, turnover of uninhibited cotransporter at the plasma membrane is the reason for restoration of glioma cell motility. It would be interesting in future experiments to utilize the scratch wound assay in combination with ${ }^{86} \mathrm{Rb}$ fluxes and immunohistochemistry to measure cotransporter turnover and localization in the presence and absence of furosemide.

Based on the combination of the loop diuretic inhibition of cell motility with another study that found greater quantities of KCC3a protein expression in human glioblastoma cell lysates [23], the role of KCC3 in cell motility of C6 glioma cells became the focus of this study. Although the decrease in the observed $\mathrm{K}^{+}$influx matched that of the decrease in protein expression, the possibility that the shRNA strategy might have targeted other KCC isoforms 


\section{Cellular Physiology Cell Physiol Biochem 2012;30:466-476 \\ \begin{tabular}{ll|l} 
and Biochemistry & $\begin{array}{l}\text { DOI: 10.1159/000339040 } \\
\text { Published online: July 06, } 2012\end{array}$ & $\begin{array}{l}\text { ○ 2012 S. Karger AG, Basel } \\
\text { www.karger.com/cpb }\end{array}$ \\
\cline { 2 - 3 } Gagnon: Role of KCC3 in Glioblastoma Motility &
\end{tabular}}

still existed. However, as shown in Table 3, the three KCC3 shRNA hairpins only matched the other KCC isoforms from $64 \%$ to $76 \%$, and as a $100 \%$ match only decreased KCC3 protein expression by $50 \%$, the likelihood that the other KCC isoforms were affected is remote.

Using short hairpin interfering RNA, the western blot, functional, and wound assay experiments indicated that either a single KCC isoform (i.e. KCC3) was not solely responsible for all $\mathrm{K}-\mathrm{Cl}$ coupled cotransport, or genetic knock-down of one isoform was compensated for by the up-regulation of another isoform (i.e. KCC1/KCC4). It is curious that several cell types (e.g. red blood cells, neurons, kidney nephron, lens epithelia) have been shown to express multiple isoforms of a membrane protein which ostensibly performs the same function [45-48]. In 2001, Alper and co-workers used a non-functional deletion mutant of KCC1 to demonstrate heterologous interaction of KCC isoforms [40]. If heterodimerization of KCC isoforms occurs in glioma cells, then genetic knock-down of KCC3 could serve as a signal to up-regulate the expression of the other KCC isoforms. Although the relative expression of the three KCC isoforms in primary cultured astrocytes and immortalized glioblastoma cells was not quantitated by real-time PCR, semi-quantitative PCR determined that both KCC1 and KCC3 exhibited similar mRNA expression levels at 25 cycles in C6 glioma cells, consistent with the Shen study $[21,22]$. The lack of equivalent KCC4 mRNA expression in either primary astrocytes or $\mathrm{C} 6$ tumor cells is consistent with western blot analysis in another study which found very low or absent KCC4 protein expression in cortex, hippocampus, and cerebellum [49]. It will be interesting in future experiments to quantitate the expression of the three KCC isoforms in untreated and shRNA knock-down glioma cell lines to determine if downregulation of one isoform alters the expression level of another isoform.

The current models for cell migration incorporate $\mathrm{K}^{+}$channels and $\mathrm{Cl}^{-}$channels as the efflux pathway for water movement [50]. In this study, loop diuretic inhibition and genetic silencing of KCC3 reduced cotransporter activity and cell motility by $50 \%$. One possible explanation for these results is loss of salt and water efflux which affects both the intracellular concentrations of chloride, as well as other intracellular proteins (e.g. signaling molecules) thereby possibly altering their ability to regulate mechanisms involved in cell motility. This hypothesis is consistent with molecular and functional evidence suggesting that expression of different $\mathrm{K}-\mathrm{Cl}$ cotransporter isoforms altered the level of intracellular chloride inhibiting the tumor suppressor retinoblastoma protein involved in the transition from G1 to S phase, and CDC2 (involved in the transition from G2 to M phase) [21, 22].

The possibility that ion transport (and obligatory water movement) through NKCC and KCC each have a role in glioblastoma migration, and that they are both regulated by kinase/ phosphatase signaling cascades, suggests that further study should examine role of the Ste20related kinases (SPAK/OSR1) and Protein Phosphatase I in glioma cell motility. Furthermore, the WNK kinases and the Apoptosis-associated tyrosine kinases (AATYKs) which both act upstream of the Ste20-related kinases and independently regulate KCC activity would also be an interesting area of future investigation. Altogether, the results from this study suggest the possibility that the presence/function of multiple isoforms of the $\mathrm{Na}^{+}$-independent $\mathrm{K}-\mathrm{Cl}$ cotransporter have a role in glioma cell motility.

\section{Acknowledgements}

I want to express my thanks to Dr. Eric Delpire (Department of Anesthesiology, Vanderbilt University School of Medicine, Nashville, TN) for his support and careful review of this manuscript. 


\begin{tabular}{|c|c|c|}
\hline \multirow{3}{*}{$\begin{array}{l}\text { Cellular Physiolosy } \\
\text { and Biochemistry }\end{array}$} & \multirow{2}{*}{$\begin{array}{l}\text { Cell Physiol Biochem 2012;30:466-476 } \\
\text { DOI: 10.1159/000339040 }\end{array}$} & \\
\hline & & $\begin{array}{l}\text { O } 2012 \text { S. Karger AG, Basel } \\
\text { www.karger.com/cpb }\end{array}$ \\
\hline & Gagnon: Role of KCC3 in Glio & \\
\hline
\end{tabular}

\section{References}

1 Preusser M, Haberler C, Hainfellner J: Malignant glioma: neuropathology and neurobiology. Wien Med Wochenschr 2006;156:332-337.

2 Reardon D, Rich J, Friedman H, Bigner D: Recent advances in the treatment of malignant astrocytoma. J Clin Oncol 2006;24:1253-1265.

3 Demuth T, Berens M: Molecular mechanisms of glioma cell migration. J Neurooncol 2004;70:217-228.

4 Scott J, Rewcastle N, Brasher P, Fulton D, Hagen N, MacKinnon J, Sutherland G, Cairncross J, Forsyth P: Longterm glioblastoma multiforme survivors: a population-based study. Can J Neurol Sci 1998;25:197-201.

5 Stupp R, Mason W, van den Bent M, Weller M, Fisher B, Taphoorn M, Belanger K, Brandes A, Marosi C, Bogdahn U, Curschmann J, Janzer R, Ludwin S, Gorlia T, Allgeier A, Lacombe D, Cairncross J, Eisenhauer E, Mirimanoff R: Radiotherapy plus concomitant and adjuvant temozolomide for glioblastoma. N Engl J Med 2005;352:987-996.

6 Giese A, Loo MA, Berens M: Determinants of human astrocytoma migration. Cancer Res 1994;54:38973904.

7 Sieg DJ, Hauck CR, Ilic D, Klingbeil CK, Schaefer E, Damsky CH, Schlaepfer DD: FAK integrates growth-factor and integrin signals to promote cell migration. Nature Cell Biology 2000;2:249-256.

8 Rao JS: Molecular mechanisms of glioma invasiveness: the role of proteases. Nature Reviews - Cancer 2003;3:489-501.

9 Giese A, Bjerkvig R, Berens M, Westphal M: Cost of migration: invasion of malignant gliomas and implications for treatment. Journal of Clinical Oncology 2003;21:1624.

10 Soroceanu L, Manning TJ Jr, Sontheimer H: Modulation of glioma cell migration and invasion using $\mathrm{Cl}^{-}$and $\mathrm{K}^{+}$ ion channel blockers. J Neurosci 1999;19:5942-5954.

11 Ransom CB, O'Neal JT, Sontheimer H: Volume-activated chloride currents contribute to the resting conductance and invasive migration of human glioma cells. J Neurosci 2001;21:7674-7683.

12 Schwab A, Wojnowski L, Gabriel K, Oberleithner H: Oscillating activity of a $\mathrm{Ca}^{2+}$-sensitive $\mathrm{K}^{+}$channel. A prerequisite for migration of transformed Madin-Darby canine kidney focus cells. J Clin Invest 1994;93:16311636.

13 Kim SU, de Vellis J: Microglia in health and disease. J Neurosci Res 2005;81:302-313.

14 Mao HJ, Li HN, Zhou XM, Zhao JL, Wan DF: Monitoring microarray-based gene expression profile changes in hepatocellular carcinoma. World J Gastroenterol 2005;11:2811-2816.

15 Geck P, Heinz E: Coupling of ion flows in cell suspension systems. Ann N Y Acad Sci 1980;341:57-66.

16 Lauf P, Bauer J, Adragna N, Fujise H, Zade-Oppen A, Ryu K, Delpire E: Erythrocyte K-Cl cotransport: properties and regulation. Am J Physiol 1992;263:C917-932.

17 Stock C, Schwab A: Role of the $\mathrm{Na}^{+} / \mathrm{H}^{+}$exchanger NHE1 in cell migration. Acta Physiol 2006;187:149-157.

18 Dunham PB, Stewart GW, Ellory JC: Chloride-activated passive potassium transport in human erythrocytes. Proc Natl Acad Sci USA 1980;77:1711-1715.

19 Geck P, Pietrzyk C, Burckhardt BC, Pfeiffer B, Heinz E: Electrically silent cotransport on $\mathrm{Na}^{+}, \mathrm{K}^{+}$and $\mathrm{Cl}^{-}$in Ehrlich cells. Biochim Biophys Acta 1980;600:432-447.

20 Haas BR, Sontheimer H: Inhibition of the Sodium-Potassium-Chloride Cotransporter Isoform-1 reduces glioma invasion. Cancer Res 2010;70:5597-5606.

21 Shen MR, Chou CY, Ellory JC: Volume-sensitive KCl cotransport associated with human cervical carcinogenesis. Pflugers Arch 2000;440:751-760.

22 Shen MR, Chou CY, Hsu KF, Hsu YM, Chiu WT, Tang MJ, Alper SL, Ellory JC: KCl cotransport is an important modulator of human cervical cancer growth and invasion. J Biol Chem 2003;278:39941-39950.

23 Ernest N, Weaver A, Van Duyn L, Sontheimer H: Relative contribution of chloride channels and transporters to regulatory volume decrease in human glioma cells. Am J Physiol Cell Physiol 2005;288:C1451-1460.

24 McCarthy KD, de Vellis J: Preparation of separate astroglial and oligodendroglial cell cultures from rat cerebral tissue. J Cell Biology 1980;85:890-902.

25 Zhou H, Xia XG, Xu Z: An RNA polymerase II construct sythesizes short-hairpin RNA with a quantitative indicator and mediates highly efficient RNAi. Nucl Acids Res 2005;33:e62.

26 Geng Y, Hoke A, Delpire E: The Ste20 kinases Ste20-related proline-alanine-rich kinase and oxidative-stress response 1 regulate NKCC1 function in sensory neurons. J Biol Chem 2009;284:14020-14028.

27 Geback T, Shulz MM, Koumoutsakos P, Detmar M: TScratch: a novel and simple software tool for automated analysis of monolayer wound healing assays. Biotechniques 2009;46:265-274. 


\section{Cellular Physiology Cell Physiol Biochem 2012;30:466-476 \\ \begin{tabular}{ll|l} 
and BiOChemistry & $\begin{array}{l}\text { DOI: 10.1159/000339040 } \\
\text { Published online: July 06, 2012 }\end{array}$ & $\begin{array}{l}\text { (c) 2012 S. Karger AG, Basel } \\
\text { www.karger.com/cpb }\end{array}$ \\
\cline { 2 - 2 } & Gagnon: Role of KCC3 in Glioblastoma Motility
\end{tabular}}

28 Benda P, Lightbody J, Sato G, Levine L, Sweet W: Differentiated rat glial cell strain in tissue culture. Science 1968;161:370-371.

29 Chassande O, Frelin C, Farahifar D, Jean T, Lazdunski M: The $\mathrm{Na}^{+} / \mathrm{K}^{+} / \mathrm{Cl}$ cotransport in C6 glioma cells. Properties and role in volume regulation. Eur J Biochem 1988;171:425-433.

30 Kempski O, Staub F, Schneider GH, Weigt H, Baethmann A: Swelling of C6 glioma cells and astrocytes from glutamate, high $\mathrm{K}^{+}$concentrations or acidosis. Prog Brain Res 1992;94:69-75.

31 Penar PL, Khoshyomn S, Bhushan A, Tritton TR: Inhibition of glioma invasion of fetal brain aggregates. In Vivo 1998;12:75-84.

32 Zhu Z, Kimura M, Itokawa Y, Nakatsu S, Oda Y, Kikuchi H: Effect of selenium on malignant tumor cells of brain. Biol Trace Elem Res 1995;49:1-7.

33 Grobben B, Paul De Deyn P, Slegers H: Rat C6 glioma as experimental model system for the study of glioblastoma growth and invasion. Cell Tissue Res 2002;310:257-270.

34 Gamba G: Molecular Physiology and Pathophysiology of Electroneutral Cation-Chloride Cotransporters. Physiol Rev 2005;85:423-493.

35 Gagnon KB, Adragna NC, Fyffe RE, Lauf PK: Characterization of glial cell K-Cl cotransport. Cell Physiol Biochem 2007;20:121-130.

36 Paddison PJ, Caudy AA, Bernstein E, Hannon GJ, Conklin DS: Short hairpin RNAs (shRNAs) induce sequencespecific silencing in mammalian cells. Genes \& Dev 2002;16:948-958.

37 Klein CA: Cancer. The metastasis cascade. Science 2008;321:1785-1787.

38 Krex D, Klink B, Hartmann C, von Deimling A, Pietsch T, Simon M, Sabel M, Steinbach JP, Heese O, Reifenberger G, Weller M, Schackert G: Long-term survival with glioblastoma multiforme. Brain 2007;130:2596-2606.

39 Shen MR, Chou CY, Ellory JC: Swelling-activated taurine and $\mathrm{K}^{+}$transport in human cervical cancer cells: association with cell cycle progression. Pflugers Arch 2001;441:787-795.

40 Casula S, Shmukler BE, Wilhelm S, Stuart-Tilley AK, Su W, Chernova MN, Brugnara C, Alper SL: A dominant negative mutant of the $\mathrm{KCC} 1 \mathrm{~K}-\mathrm{Cl}$ cotransporter: both $\mathrm{N}$ - and C-terminal cytoplasmic domains are required for K-Cl cotransport activity. J Biol Chem 2001;276:41870-41878.

41 Shen MR, Lin AC, Hsu YM, Chang TJ, Tang MJ, Alper SL, Ellory JC, Chou CY: Insulin-like growth factor 1 stimulates $\mathrm{KCl}$ cotransport, which is necessary for invasion and proliferation of cervical cancer and ovarian cancer cells. J Biol Chem 2004;279:40017-40025.

42 Shen MR, Hsu YM, Hsu KF, Chen YF, Tang MJ, Chou CY: Insulin-like growth factor 1 is a potent stimulator of cervical cancer cell invasiveness and proliferation that is modulated by alphavbeta3 integrin signaling. Carcinogenesis 2006;27:962-971.

43 Hsu Y, Chou C, Chen H, Lee W, Chen Y, Lin P, Alper S, Ellory J, Shen M: IGF-1 upregulates electroneutral K$\mathrm{Cl}$ cotransporter KCC3 and KCC4 which are differentially required for breast cancer cell proliferation and invasiveness. J Cell Physiol 2007;210:626-636.

44 Hsu YM, Chen YF, Chou CY, Tang MJ, Chen JH, Wilkins RJ, Ellory JC, Shen MR: KCl cotransporter-3 downregulates E-cadherin/beta-catenin complex to promote epithelial-mesenchymal transition. Cancer Res 2007;67:11064-11073.

45 Holtzman EJ, Kumar S, Faaland CA, Warner F, Logue PJ, Erickson SJ, Ricken G, Waldman J, Dunham PB: Cloning, characterization, and gene organization of $\mathrm{K}-\mathrm{Cl}$ cotransporter from pig and human kidney and C. elegans. Am J Physiol 1998;275:F550-564.

46 Payne JA, Stevenson TJ, Donaldson LF: Molecular characterization of a putative K-Cl cotransporter in rat brain. A neuronal-specific isoform. J Biol Chem 1996;271:16245-16252.

47 Mount DB, Mercado A, Song L, Xu J, George AL Jr, Delpire E, Gamba G: Cloning and characterization of KCC3 and KCC4, new members of the cation-chloride cotransporter gene family. J Biol Chem 1999;274:1635516362.

48 Lauf PK, Di Fulvio M, Srivastava V, Sharma N, Adragna NC: KCC2a expression in a human fetal lens epithelial cell line. Cell Phys Biochem 2012;29:303-312.

49 Karadsheh MF, Byun N, Mount DB, Delpire E: Localization of the KCC4 potassium-chloride cotransporter in the nervous system. Neuroscience 2004;123:381-391.

50 Lang F, Busch GL, Ritter M, Volkl H, Waldegger S, Gulbins E, Haussinger D: Functional significance of cell volume regulatory mechanisms. Physiol Rev 1998;78:247-306. 